\title{
Activation of the Granzyme Pathway in Children With Severe Respiratory Syncytial Virus Infection
}

\author{
REINOUT A. BEM, ALBERT P. BOS, MICHAEL BOTS, ANGELA M. WOLBINK, S. MARIEKE VAN HAM, JAN PAUL MEDEMA, \\ RENE LUTTER, AND JOB B. M. VAN WOENSEL
}

\begin{abstract}
Pediatric Intensive Care Unit [R.A.B., A.P.B., J.B.M.W.], Laboratory for Experimental Oncology and Radiobiology [M.B., J.P.M.], and Departments of Pulmonology and Experimental Immunology [R.L.], Academic Medical Center, Amsterdam, 1100 DD, The Netherlands; Department of Immunopathology [A.M.W., S.M.H.], Academic Medical Center, Amsterdam, 1066 CX, The Netherlands
\end{abstract}

\begin{abstract}
Granzymes (Grs), serine proteases present in granules of effector lymphocytes, are involved in several host immune responses, including the activation of cell death and inflammatory pathways. The main goal of this study was to determine whether the local cell-mediated Gr pathway is activated during severe respiratory syncytial virus (RSV) lower respiratory tract illness (LRTI) in children. Tracheal aspirates (TA) from 23 children with RSV-LRTI and 12 controls without pulmonary disease were analyzed for Gr A and B. Bronchoalveolar lavage fluid samples from seven children with RSV-LRTI were analyzed for cellular expression of GrB. Levels of GrA and GrB in TA were significantly increased in RSV patients compared with controls and both Grs showed preserved activity. $\mathrm{Gr}$ levels correlated with the total leukocyte counts and IL- 8 levels in the airways at several time points. However, no correlation between $\mathrm{Gr}$ levels and release of caspase-cleaved cytokeratin-18 was found. There was evidence for marked expression of GrB by both $\mathrm{CD}^{+}$and $\mathrm{CD}^{+} \mathrm{T}$ cells and natural killer cells in the respiratory tract. These findings suggest activation of the cell-mediated Gr pathway during severe RSV-LRTI in children. (Pediatr Res 63: 650-655, 2008)
\end{abstract}

$\mathrm{R}^{\mathrm{s}}$ espiratory syncytial virus (RSV) is a major respiratory pathogen among infants and young children (1). Although in general, RSV infection is limited to the upper respiratory tract, the disease may progress to the lower airways leading to acute hypoxemic respiratory failure. The most severe cases of RSV-lower respiratory tract illness (RSVLRTI) fulfill the criteria of acute lung injury (ALI) or the acute respiratory distress syndrome (ARDS) (2). Despite decades of research, the exact mechanisms that determine the development of severe RSV-LRTI in previously healthy children remain unclear.

One hypothesis proposes that activation of cell death pathways directed against RSV-infected cells and/or uninfected bystander cells contributes to disease severity (3). Although regulated cell death or apoptosis seems an important mechanism for RSV clearance, Welliver et al. showed marked expression of the apoptosis marker caspase-3 in airway epithelium of children with fatal RSV-LRTI, suggesting an im-

Received October 29, 2007; accepted January 30, 2008.

Correspondence: R.A. Bem, M.D., Emma Children's Hospital, Academic Medical Center, Pediatric Intensive Care Unit, P.O. Box 22660, 1100 DD, Amsterdam, The Netherlands; e-mail: r.a.bem@amc.uva.nl

Supported by a grant from the Dutch Cancer Society and the Association for International Cancer Research (to M.B., J.P.M.) and the Landsteiner Foundation for Blood Research (LSBR, grant 0212, to A.M.W.). balance in this process $(4,5)$. Interestingly, increasing evidence implicates epithelial apoptosis in the pathogenesis of ALI/ARDS (6). Several studies demonstrated increased expression of classical apoptotic mediators such as FasL and granzymes (Grs) in the lungs of adults with ALI/ARDS correlating with disease severity $(7,8)$. These findings implicate enhanced activation of apoptotic pathways in the pathogenesis of acute inflammatory lung diseases and may be relevant for severe RSV-LRTI in children.

In antiviral host immune response an important cell death pathway is the granule exocytosis pathway involving the serine proteases $\mathrm{GrA}$ and $\mathrm{GrB}$, which is exploited by $\mathrm{CD} 8^{+}$ T-lymphocytes (CTLs) and natural killer (NK) cells [reviewed elsewhere (9)]. Grs induce rapid cell death when directed into a target cell, and this mechanism is facilitated by the protein perforin but may also occur independently from perforin (10). Detection of free extracellular GrA and GrB is considered to reflect cytotoxic activation of the cell-mediated immune response $(11,12)$. However, proteolytic active extracellular Grs may also contribute to the activation of pro-inflammatory cytokine release and degradation of the extracellular matrix, indicating that Grs may be involved in several mechanisms of the host immune response (13).

Studies investigating the cell-mediated immune response in the lungs of children with RSV-LRTI have reported limited numbers of effector lymphocytes $(5,14)$, although in rodents both CTLs and NK cells are recruited to the lungs upon primary RSV infection where they appear to contribute to disease pathogenesis (15-17). In the present study, we hypothesized that severe RSV-LRTI in children is associated with local activation of the Gr pathway by the cell-mediated host immune response. To test this, we investigated extracellular GrA and $\mathrm{GrB}$ and cellular expression of $\mathrm{GrB}$ in the respiratory tract of infants with RSV-LRTI.

\section{METHODS}

Patients and sample collection. All protocols were approved by the Academic Medical Center ethical committee and informed consent was

Abbreviations: BALF, bronchoalveolar lavage fluid; CTL, cytotoxic Tlymphocyte; Gr, granzyme; MV, mechanical ventilation; NK, natural killer; RSV-LRTI, respiratory syncytial virus lower respiratory tract illness; TA, tracheal aspirate 
obtained from parents. Tracheal aspirate (TA) samples were obtained from 23 children with RSV-LRTI and 12 age-matched controls without a pulmonary condition. All patients were admitted to the intensive care unit for mechanical ventilation (MV) between November 2003 and March 2006. Infection with RSV was proven by direct immunofluorescence assay (Imagen, DakoCytomation, UK) of nasopharyngeal aspirate. As part of an international randomized placebo-controlled trial on the use of glucocorticosteroids during RSVLRTI (www.star-trial.com), RSV patients received dexamethasone $0.15 \mathrm{mg} /$ $\mathrm{kg} / \mathrm{dose}$, i.v. or placebo (QID, eight doses in total) starting within $24 \mathrm{~h}$ after start of MV. Oxygenation index calculated as $\left(\mathrm{FiO}_{2} \times\right.$ mean airway pressure $\left.\left(\mathrm{cmH}_{2} \mathrm{O}\right) \times 100\right) / \mathrm{PaO}_{2}(\mathrm{kPa})$, during the first $24 \mathrm{~h}$ was used to assess severity of oxygenation anomaly. If more than one arterial blood gas was obtained, the best index was chosen. Pediatric risk of mortality (PRISM) scores were used as a measure of disease severity.

TA was collected as described before (18). Aspirate was collected without previous installation of fluids on the day of start of MV and in the RSVpatients on day 2 and 4 as long as the patient was intubated. An arterial blood sample was obtained from $15 \mathrm{RSV}$-patients on the day of start of MV.

Sample processing. After determination of the volume of the aspirate sample, an equal volume of cold $10 \mathrm{mM}$ DTT (Sigma Chemical Co.-Aldrich, St. Louis, MO) in $25 \mathrm{mM}$ HEPES (N-2-hydroxyethylpiperazine- $\mathrm{N}^{\prime}-2-$ ethanesulfonic acid) $\mathrm{pH} 8.0$ was added at $4^{\circ} \mathrm{C}$ followed by 15 min mixing. If the aspirate remained mucoid this process was repeated once with a similar amount of DTT. Remaining cellular aggregates were cleared by adding DNAse (Sigma Chemical Co.-Aldrich) at $4^{\circ} \mathrm{C}$. Cells in processed aspirate were collected by centrifugation at $450 \mathrm{~g}$ for $10 \mathrm{~min}$. Supernatant was aspirated, aliquoted, and stored at $-80^{\circ} \mathrm{C}$. The cell pellet was resuspended in PBS, and total white blood cells (WBC) were counted in a Bürker bright line counting chamber. Air-dried cytospins were stained with Romanovsky (DiffQuick) and differential WBC counts were obtained by counting 300 leukocytes using a standard light microscope. Reliable differential counts could not be obtained in $18 \%$ of the samples because of debris and some degeneration of cells.

Immunoassays. Extracellular GrA and GrB were measured by immunoassays (Sanquin, the Netherlands) according to the manufacturer's description. Interleukin (IL)-8 was measured by immunoassay using monoclonal antibody (MAb) against IL-8 (R\&D Systems) for capture and detection. Extracellular caspase-cleaved cytokeratin-18 (CK18), a marker of epithelial cell apoptosis, was measured using the M30-Apoptosense sandwich immunoassay (Peviva AB, Sweden). The M30 antigen levels are expressed as Units/mL, where $1 \mathrm{U}$ corresponds to $1.24 \mathrm{pmol}$ of recombinant M30containing peptide. Assay lower limit: $0.7 \mathrm{U} / \mathrm{mL}$.

TA samples were diluted minimally $1: 100$ (GrA/B and IL-8) and 1:20 (cleaved CK18) to overcome interference of DTT with the assays and serial dilutions were tested. All reported antigen levels in TA are corrected for the sample processing dilution factor.

Granzyme activity. Activity of GrA was measured by a recently developed immunoassay as described elsewhere (19). For measurement of GrB activity, $\mathrm{GrB}$ in samples was captured on microtiter plates coated with anti-GrB MAb GB-11 (2 $\mu \mathrm{g} / \mathrm{mL}$ in $0.1 \mathrm{M}$ sodium carbonate/bicarbonate buffer, $\mathrm{pH} 5.5)$. The plates were then washed and incubated with GrB-specific chromogenic substrate Ac-Ile-Glu-Thr-Asp-pNA [Alexis Biochemicals, Lausen, Switzerland; $0.4 \mathrm{mM}$ in $50 \mathrm{mM}$ Tris, $100 \mathrm{mM} \mathrm{NaCl}$ and $0.1 \%$ Tween (vol/ $/ \mathrm{vol}$ ), $\mathrm{pH}$ 7.4]. GrB activity was measured for $4 \mathrm{~h}$ at $37^{\circ} \mathrm{C}$ at an absorbance (A) of 405 $\mathrm{nm}$ on a Titer-Tek Multiscan (Labsystems, Helsinki, Finland) and is expressed as deltaA per hour.

Fluorescent-activated cell sorting (FACS) analysis. FACS analysis was performed in bronchoalveolar lavage fluid (BALF) samples from mechanically ventilated children with RSV-LRTI in the winters of 2006-2008. BALF was obtained by three subsequent instillations of $1 \mathrm{~mL} / \mathrm{kg}$ of $0.9 \%$ saline through a wedged suction catheter passed through the endotracheal tube. After each instillation, fluid was suctioned (mean \pm SE recovery: $36 \% \pm 4$ ). The last two samples were pooled and $10 \mathrm{~min}$ centrifuged at $450 \mathrm{~g}$. The pooled BALF cells in FACS buffer ( $0.5 \%$ BSA, $0.02 \%$ potassium-EDTA in PBS) containing $10 \%$ normal human serum were labeled with APC-labeled antiCD3, PerCPCy5-labeled CD8 or -CD4 (BD Pharmingen, San Jose, CA) and FITC-labeled anti CD16 (Sanquin, the Netherlands) and -56 (BD Pharmingen). For intracellular GrB staining cells were fixed and permeabilized with fixation/permeabilization solution (BD Pharmingen) and stained with PElabeled anti-GrB MAb (Sanquin) or a PE-labeled isotype control (BD Pharmingen). Cells were analyzed using a FACSCalibur flow cytometer and CellQuest Pro software (BD Biosciences).

Statistical analysis. Not normally distributed data are expressed as medians and were analyzed by using the Mann-Whitney $U$ test for differences between groups. For normally distributed data, a Student $t$ test was used to compare group means. Spearman's correlation coefficient was calculated to assess the degree of association between Grs and studied markers. Proportions
Table 1. Baseline patient characteristics

\begin{tabular}{lccr}
\hline & Control* & \multicolumn{1}{c}{ RSV } & \multicolumn{1}{c}{$p$} \\
\hline No. patients & 12 & 23 & \\
Age, months, median (IQR) & $3.5(6.6)$ & $1.5(1.0)$ & 0.10 \\
Male, $n(\%)$ & $6(50)$ & $15(65)$ & 0.48 \\
Duration of symptoms, d, median (IQR) & $\mathrm{NA}$ & $3(2)$ & \\
PRISM score, median (IQR) & $6(6) \dagger$ & $10(8)$ & 0.09 \\
Oxygenation index, median (IQR) & $1.4(0.5) \ddagger$ & $4.4(4.3)$ & $<0.01$ \\
Positive bacterial culture TA, $n(\%) \S$ & $0(0)$ & $5(22)$ & 0.14 \\
Duration of MV before 1st sample, h, & $9.5(12.8)$ & $19(9)$ & 0.15 \\
$\quad$ & & & \\
\hline
\end{tabular}

* Reason for admission and mechanical ventilation of control patients were: metabolic disorder $(n=1)$, intracardial rhabdomyoma $(n=1)$, convulsions $(n=1)$, pneumococcal meningitis $(n=1)$, cardiomyopathy $(n=$ 1) and, postoperative $(n=7$ : abdominal surgery $(n=4)$, craniosynostosis $(n=1)$, closure of persistent ductus arteriosis $(n=1)$, congenital diaphragmatic hernia, $(n=1)$.

$\dagger(n=9)$ Of 3 controls no PRISM score was available at the time of TA sampling.

$\ddagger(n=8)$ No arterial blood gas analysis was obtained in 4 controls.

$\S$ On day of start of mechanical ventilation. MV: mechanical ventilation.

Table 2. Total white blood cell (WBC) counts and differentials in TA samples of mechanically ventilated patients without pulmonary disease (controls) and RSV patients on the day of start of mechanical ventilation

\begin{tabular}{ccc}
\hline & \multicolumn{1}{c}{ Control } & RSV \\
\hline Total WBC count $\left(\times 10^{6} / \mathrm{mL}\right)$, & $6.8(7.7)$ & $28.6(54.8)^{*}$ \\
median (IQR) & & \\
Differentials in \%, & & \\
median (range): & $81.4(36.0-92.7)$ & $88.5(70.0-94.3)$ \\
Neutrophils & $18.3(7.3-64.0)$ & $11.2(5.0-30.0)$ \\
Monocytes/Macrophages & $0(0-2)$ & $1.0(0-2)$ \\
Lymphocytes & & \\
\hline
\end{tabular}

$* p<0.05$, Mann-Whitney $U$ test.

in the patient groups were compared by Fisher's exact test. A two-sided $p$ value of $<0.05$ was considered statistically significant.

\section{RESULTS}

Baseline patient characteristics. The baseline characteristics of the patients are shown in Table 1. Ten RSV patients (43\%) had received dexamethasone as part of the aforementioned randomized placebo-controlled trial. Total WBC counts and differentials in TA samples of controls and RSV patients are shown in Table 2.

Elevated GrA and GrB in TA during severe RSV-LRTI. The median (range) level of GrA in TA on the day of start of MV was $0.6(0.3-14.3) \mathrm{ng} / \mathrm{mL}$ and $11.1(0.3-98.4) \mathrm{ng} / \mathrm{mL}$ in controls and RSV-patients respectively ( $p<0.01$, Fig. $1 A$ ). Likewise, the median (range) level of GrB in TA was higher in the RSV patients $(69.0,3.1-728.0, \mathrm{ng} / \mathrm{mL})$ compared with the controls $(1.7 \mathrm{ng} / \mathrm{mL}, 0.5-39.6, \mathrm{ng} / \mathrm{mL})(p<0.01$, Fig. $1 B)$. There was a significant correlation between the levels of GrA and $\mathrm{GrB}$ in TA (Spearman $r=0.67, p<0.001$ ). In the RSV patients, the plasma levels of GrA (median 63.0, range 3.0180.0, pg/mL) and GrB (median 35.0, range 13.0-92.0, pg/ $\mathrm{mL}$ ) on the first day of MV were significantly lower than the levels in TA $(p<0.001$ for both comparisons, data not shown). 

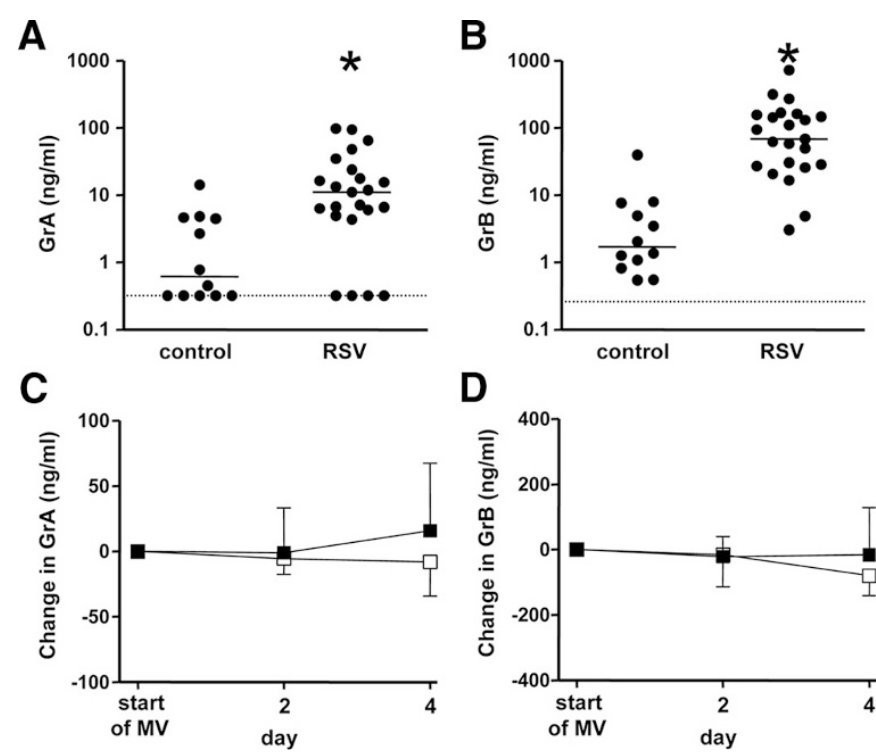

D

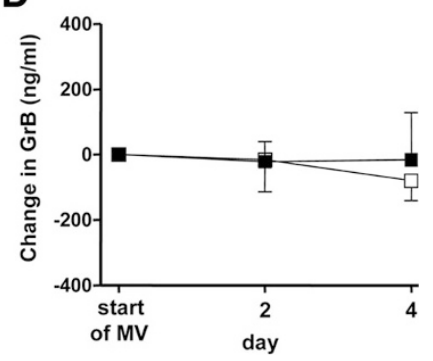

Figure 1. $(A-B)$ Levels of GrA and $\mathrm{GrB}(\mathrm{ng} / \mathrm{mL})$ in TA from children without pulmonary condition (controls, $n=12)$ or with RSV-LRTI $(n=23)$ on the day of start of mechanical ventilation (MV). Bars represent median values. Dotted lines represent lowest detectable levels. ${ }^{*} p<0.01$. $(C-D)$ Relative change of median levels of GrA and GrB in TA on day $2(n=23)$ and day $4(n=14)$ from baseline (day of start of MV, $n=23)$ in RSV patients who received placebo $(\square, n=13)$ or dexamethasone $(\square, n=10)$ treatment. Error bars show the 25 th or 75 th percentile. $p=n . s$.

GrA and GrB in TA were detected throughout the course of RSV-LRTI, but no effect of dexamethasone as compared with placebo on the Gr levels was found (Fig. $1 C$ and $D$ ). No difference in Gr levels was found between RSV patients with or without a positive bacterial culture of TA.

GrA and GrB in TA have retained activity. To ascertain biologic activity of GrA and GrB in the airways of RSV patients we measured active GrA and GrB with enzyme capture assays. Because the sensitivity of these assays was $50 \mathrm{pg} / \mathrm{mL}$ and 1 $\mathrm{ng} / \mathrm{mL}$ respectively, only 10 samples of TA containing high levels of GrA and GrB were measured. There was a significant correlation between the levels of active GrA and total GrA antigen (Spearman $r=0.82, p<0.01$ ) (Fig. 2A). In addition, we found a positive correlation between $\mathrm{GrB}$ activity and total $\mathrm{GrB}$ antigen (Spearman $r=0.62, p=0.05$ ) (Fig. 2B).

Granzymes in TA correlate with inflammatory markers, but not with cleaved-CK18. There was a positive correlation between GrA and GrB and total WBC counts and IL-8 in TA
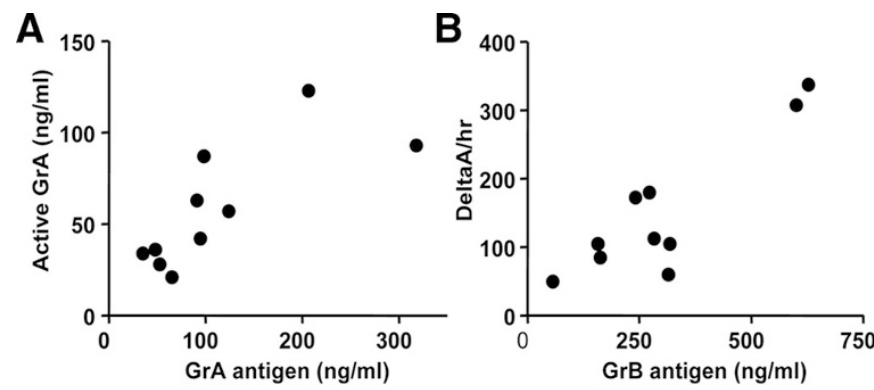

Figure 2. (A) Correlation between the levels $(\mathrm{ng} / \mathrm{mL})$ of $\mathrm{GrA}$ antigen and active GrA in TA (Spearman $r=0.82, p<0.01$ ). (B) Correlation between the level of total $\mathrm{GrB}$ antigen $(\mathrm{ng} / \mathrm{mL})$ and $\mathrm{GrB}$ proteolytic activity (deltaA per hr) in TA (Spearman $r=0.62, p=0.05$ ).
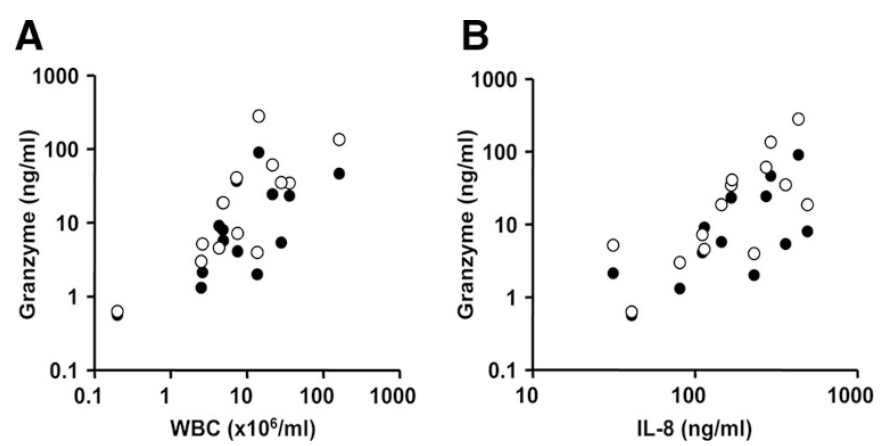

Figure 3. (A) Correlation between the levels of $\operatorname{GrA}(\bullet)$ or $\operatorname{GrB}(\bigcirc)$ and total white blood cell counts $(A)$ and IL-8 levels $(B)$ in TA of RSV patients on day 4 after start of MV. Spearman $r>0.63(p<0.05)$ for all comparisons.

in the RSV patients and this correlation tended to be stronger after the first days of MV (Fig. 3). However, no correlation between Gr levels and disease severity at baseline, as determined by PRISM scores and oxygenation index, was found (data not shown).

To study lung epithelial apoptosis in relation to extracellular Grs, we analyzed the correlation between GrB and cleavedCK18 in TA. CK-18 is an epithelium-specific intermediate filament protein which is cleaved by caspases early during apoptosis and may be subsequently released from cells into the extracellular space (20). Caspases are activated by GrB, but not by GrA. There was no significant correlation between $\mathrm{GrB}$ and cleaved-CK18 in TA at any time point. Also, no statistically significant difference between cleaved-CK18 levels $(\mathrm{U} / \mathrm{mL}$ ) of controls (median 14.5, IQR 39.2) compared with the RSV patients (median 8.4, IQR 17.7) was found ( $p=$ $0.20)$.

GrB expression by lymphocytes in BALF. To find a potential source of Grs in the lungs of children with severe RSV-LRTI, we performed FACS analysis in BALF samples in an additional cohort of mechanically ventilated children (mean age $1.4 \pm 0.2 \mathrm{mo}, n=7$ ) with RSV-LRTI. These patients did not differ from the original cohort in terms of age, gender distribution, and duration of illness (data not shown). T cells and NK cells were detected in low numbers throughout the course of RSV-LRTI (Table 3). GrB-positive cells were found predominantly among cells within the side/forward scatter region of the lymphocyte population (Fig. $4 A-E$ ). In addition to $\mathrm{CD} 8^{+} \mathrm{T}$ cells and $\mathrm{NK}$ cells, $\mathrm{CD} 8^{-} \mathrm{T}$ cells were

Table 3. Mean percentages $\pm S E$ (of total cells) of cells expressing $\mathrm{CD}^{+}, \mathrm{CD}^{+} \mathrm{CD}^{+}$and $\mathrm{CD} 3^{+} \mathrm{CD} 16 / 56^{+}$(NK cells) in $B A L F$ of mechanically ventilated children with severe RSV infection, as determined by FACS analysis

\begin{tabular}{|c|c|c|c|}
\hline \multirow[b]{3}{*}{ Day } & \multicolumn{3}{|c|}{ Lymphocyte subpopulation } \\
\hline & \multicolumn{2}{|c|}{$\mathrm{CD}^{+}$} & \multirow[b]{2}{*}{$\begin{array}{l}\mathrm{CD}^{-} \mathrm{CD} 16 / 56^{+} \\
\% \text { of total cells }\end{array}$} \\
\hline & $\begin{array}{c}\% \text { of } \\
\text { total cells }\end{array}$ & $\begin{array}{c}\% \mathrm{CD}^{+} \\
\text {of total cells }\end{array}$ & \\
\hline $\begin{array}{l}\text { Start of mechanical } \\
\text { ventilation }\end{array}$ & $1.7 \pm 0.8$ & $0.6 \pm 0.3$ & $0.5 \pm 0.2$ \\
\hline 2 & $1.6 \pm 0.7$ & $0.9 \pm 0.4$ & $1.1 \pm 0.7$ \\
\hline 4 & $2.1 \pm 0.8$ & $1.3 \pm 0.5$ & $0.8 \pm 0.1$ \\
\hline
\end{tabular}

First day of mechanical ventilation: $n=7$, day $2: n=6$, day $4: n=4$. 

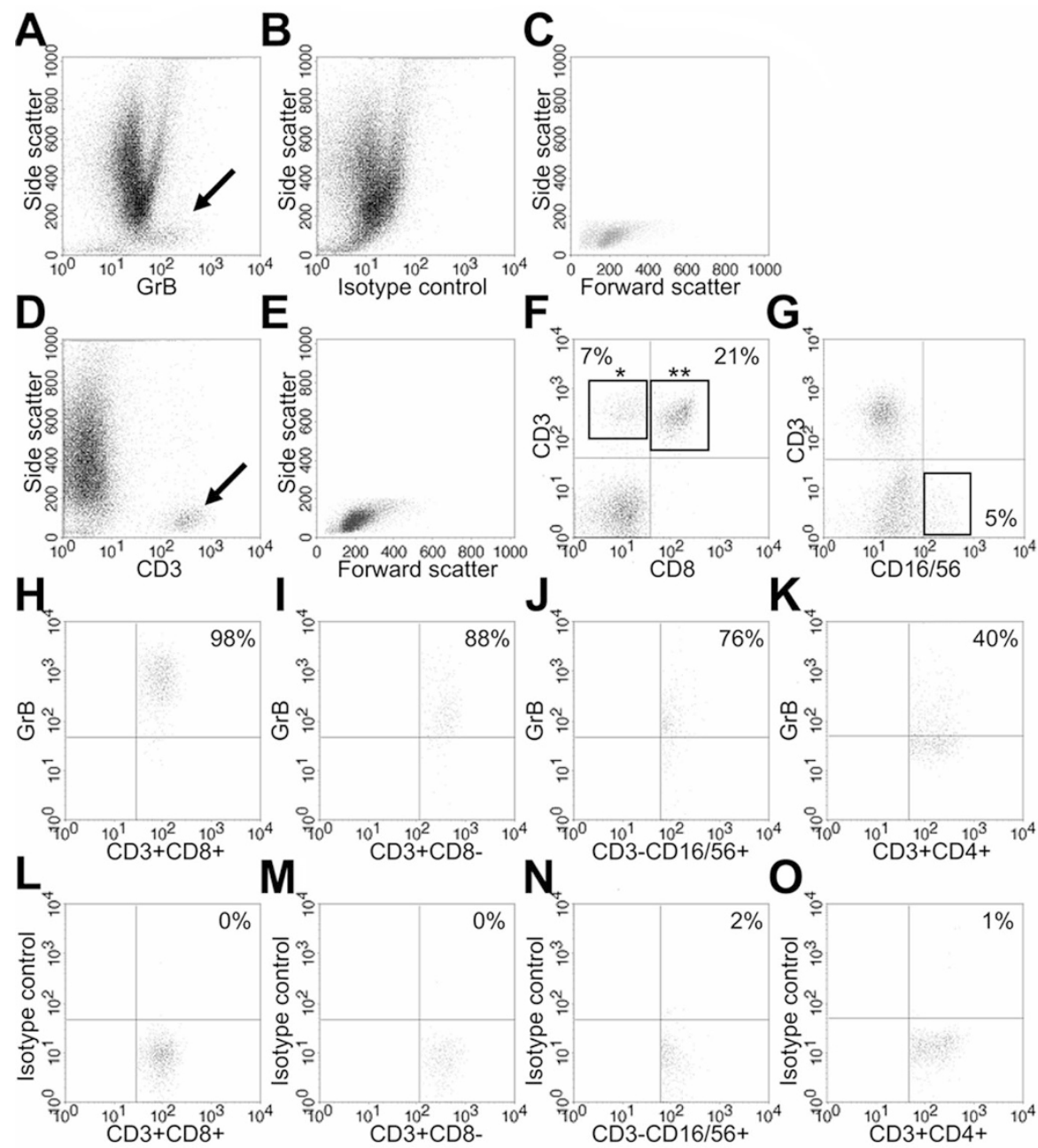

Figure 4. Representative examples of FACS scatter plots of RSV patients. (A) Side/anti-GrB MAb scatter plot showing the GrB-positive cell population (arrow), which is not detected in the same sample stained with an isotype control for $\operatorname{GrB}(B)$. (C) Side/forward scatter plot of the gated GrB-positive cell population. (D) Side/anti-CD3 MAb scatter plot showing a CD3-positive population (arrow). (E) Side/forward scatter plot of the gated CD3-positive cell population. Note that the GrBpositive cell population $(C)$ is detected in the same side/forward region as the CD3-positive cell population. $(F)$ Anti-CD3/anti-CD8 MAb scatter plot of a gated lymphocyte region (see $E$ ) showing $\mathrm{CD}^{+}{ }^{+} \mathrm{CD} 8^{-}$cells $(*)$ and $\mathrm{CD} 3^{+} \mathrm{CD} 8^{+}$cells $(* *)$. $(G)$ Anti-CD3/anti-CD16/56 MAb scatter plot of a gated lymphocyte region (see $E$ ) showing $\mathrm{CD}^{-} \mathrm{CD} 16 / 56^{+}(\mathrm{NK})$ cells. $(H)$ Anti-GrB/anti$\mathrm{CD} 8 \mathrm{MAb}$ scatter plot of a gated $\mathrm{CD} 3^{+} \mathrm{CD} 8^{+}$cell population $[(L)$ Corresponding GrB isotype control plot]. (I) Anti-GrB/anti-CD3 MAb plot of a gated $\mathrm{CD}^{+}{ }^{+} \mathrm{CD} 8{ }^{-}$cell population $[(M)$ Corresponding GrB isotype control plot]. ( $J$ ) Anti-GrB/ anti-CD16/56 MAb plot of a gated $\mathrm{CD}^{-}{ }^{-} \mathrm{CD} 16 /$ $56^{+}$cell population $[(N)$ Corresponding $\mathrm{GrB}$ isotype control plot]. $(K)$ Anti-GrB/anti-CD4 $\mathrm{MAb}$ plot of a gated $\mathrm{CD} 3{ }^{+} \mathrm{CD} 4^{+}$cell population $[(O)$ Corresponding GrB isotype control plot]. found to express GrB (Fig. $4 F-J$ ). This latter observation suggests that besides $\mathrm{CD} 4^{-} \mathrm{CD} 8^{-} \mathrm{T}$ cells (which may include gamma/delta $\mathrm{T}$ cells) $\mathrm{CD} 4^{+} \mathrm{T}$ cells may express $\mathrm{GrB}$, which was confirmed in an additional FACS analysis of four RSV patients (Fig. $4 K$ ). The percentages of GrB-positive $\mathrm{T}$ cells and NK cells and corresponding mean fluorescence intensity are shown in Figure 5.
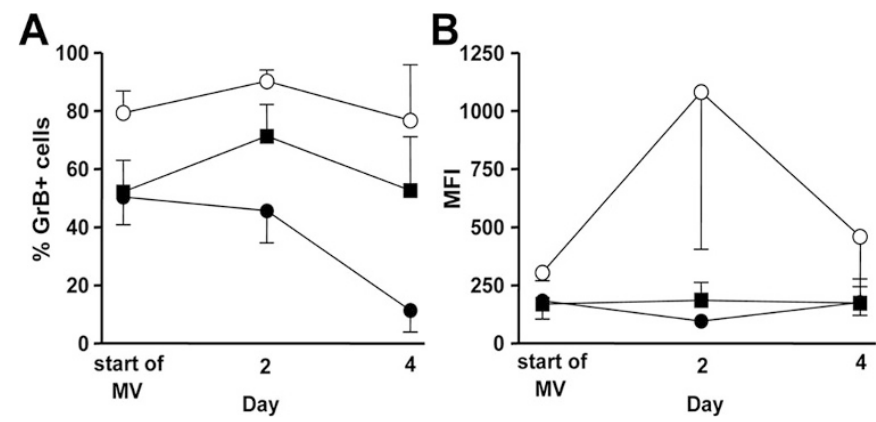

Figure 5. Mean percentages $(A)$ and mean fluorescence intensity $(B)$ of GrB-positive CTLs $\left(\mathrm{CD}^{+}{ }^{+} \mathrm{CD} 8^{+}: \bigcirc\right), \mathrm{CD}^{+} \mathrm{CD} 8-$ cells $(\square)$ and NK cells $\left(\mathrm{CD}^{-} \mathrm{CD} 16 / 56^{+}: \bullet\right)$ in BALF throughout the course of severe RSV-LRTI. First day of mechanical ventilation: $n=7$, day $2: n=6$, day $4: n=4$. Error bars show the SE.

\section{DISCUSSION}

The main goal of this study was to determine whether severe RSV infection in children is associated with local activation of the Gr pathway by the cell-mediated host immune response. We report high levels of proteolytic active extracellular GrA en GrB and marked expression of $\mathrm{GrB}$ by T-lymphocytes and NK cells in the respiratory tract of children during the course of severe RSV-LRTI. The levels of extracellular GrA and GrB correlated with total WBC counts and IL-8 levels in the airways after the acute-onset of RSV disease, but no association with the epithelium apoptosis marker cleaved-CK18 could be demonstrated.

The present study extends our understanding of cellmediated cytotoxic responses during severe RSV-LRTI in children. Numerous rodent studies have shown that both NK cells and CTLs are recruited to the lungs during primary RSV infection (15-17). Graham et al. reported that although CTLs are involved in the clearance of RSV, depletion of these lymphocytes diminishes clinical illness upon exposure to RSV (15). Treatment of RSV-infected CTL depleted mice with high dose RSV-specific CTLs results in viral clearance, but augments lung injury by causing severe hemorrhage and neutrophilic infiltration (21). These findings suggest that cell- 
mediated cytotoxic responses play an important role in RSV disease pathogenesis in mice, but the relevance in humans is unclear. In vitro studies show that CTLs isolated from peripheral blood of RSV infected infants lyse infected autologous target cells $(22,23)$. However, Welliver et al. recently reported the near absence of CTLs and NK cells in lung tissues from nine infants who died of RSV-LRTI (5). Previous analysis of BALF samples of RSV-infected children showed that a small percentage of the total cells in the lungs is CD8-positive (14). Similarly, in the present study we found low numbers of T-lymphocytes and NK cells in the lungs. However, despite these low cell counts, we report high levels of extracellular Grs and marked GrB expression in these cell populations in the respiratory tract.

The activation of the cell-mediated Gr response in children with severe RSV-LRTI raises the possibility that this cell death pathway is involved in RSV disease pathogenesis. Direct killing of infected cells by Grs is considered a major host defense mechanism against viruses in general. In mice, both GrA and $\mathrm{GrB}$ are essential in controlling ectromelia and cytomegalovirus infection $(24,25)$. Interestingly, viruses have been reported to encode proteins that inhibit Grs, suggesting pathogen immune evasive adaptations $(26,27)$. On the other hand, enhanced death of infected cells and/or bystander cells may contribute to the development of disease by causing tissue dysfunction as has been suggested for severe inflammatory lung diseases $(6,7,28)$. Welliver et al. found marked expression of caspase-3 in airway epithelium of children with fatal RSV-LRTI, a finding consistent with studies performed in adult patients with ALI/ARDS $(5,29)$. The study of Welliver et al. suggests an imbalance in apoptosis during severe RSV-LRTI, but the involved cell death pathways remain unclear. Our findings may point toward a role for the Gr pathway in apopotic cell death during severe RSV-LRTI, but contrary to our expectations, we found no correlation between the levels of extracellular GrB and caspase-cleaved CK18 in the airways. The release of caspase cleaved CK18 is a surrogate marker of epithelial apoptosis but has not been studied extensively in vivo. The detection of cleaved CK18 in serum was found to correlate well with tissue damage in patients with hantavirus infection, but it is unclear how this protein behaves and reflects epithelial injury in other body fluids, including BALF (30). Histologic analysis of apoptosis to confirm our data are highly preferred but could not be performed in our study for obvious ethical reasons.

In addition to CTLs and NK cells, $\mathrm{CD}^{+} \mathrm{T}$ cells and basophils may express Grs $(31,32)$. Recently, neutrophils also were shown to express Grs (33), although this has been debated by others (34). In the present study, GrB-positive cells were only found among lymphocytes. CTLs seemed to contribute to GrB expression the most, but actual degranulation and subsequent Gr release may have differed between the studied cell populations. The highest GrB expression by NK cells occurred on the first day of admission, before the peak of GrB expression by $\mathrm{T}$ cells. Similarly, in RSV infected mice the cytotoxic activity of NK cells is highest before CTLs are recruited to the lungs (16). Remarkably, Gr levels in the airways during severe RSV-LRTI were not affected by treat- ment with dexamethasone, although several studies in vitro have shown suppression of CTL and NK cytotoxic activity by corticosteroids $(35,36)$.

Our finding of $\mathrm{GrB}$ expression by $\mathrm{CD} 4^{+} \mathrm{T}$-lymphocytes is interesting because it suggests that the Gr pathway may be used to modulate immune responses to RSV. Devadas et al. have shown that $\mathrm{T}_{\mathrm{H}} 2$ cells express $\mathrm{GrB}$ which induces their own cell death (37). Furthermore, they reported that GrB deficient mice have augmented $\mathrm{T}_{\mathrm{H}} 2$ cytokine responses and lung cellular infiltrations in a model of allergic inflammation. Grossman et al. have shown that the Gr pathway is exploited by natural T-regulatory cells $\left(\mathrm{CD} 4{ }^{+} \mathrm{CD} 25^{+}\right)$against autologous activated $\mathrm{CD} 8^{+}$and $\mathrm{CD} 4^{+} \mathrm{T}$ cells (38). These findings suggest that Grs function to control immune responses, in addition to their role in direct virus-infected cell killing. In contrast, another line of research proposes that Grs actively participate in the activation of pro-inflammatory responses. For example, studies in vitro have shown that proteolytic active GrA induces the release of IL- 6 and IL- 8 from epithelial cells and lung fibroblasts (13). In the present study, Gr levels significantly correlated with IL-8 levels in the airways during severe RSV-LRTI and with total WBC counts after the acute phase of respiratory failure. Moreover, we found evidence that active forms of GrA as well as GrB were present, confirming the potential to exert a biologic function.

This study has three potential limitations. First, all patients had severe acute hypoxemic respiratory failure necessitating MV and thus represent the end of the spectrum of RSV disease. This withholds us from drawing firm conclusions when relating the extent of activation of the Gr pathway with markers of disease severity such as PRISM scores and oxygenation index. Second, because all patients (including controls) were subjected to MV and supplemental oxygen it is possible that this might have had (synergistic) effects on $\mathrm{Gr}$ levels, inflammation or apoptosis. Third, soluble Grs were measured in TA that may reflect more localized (and thus variable) proximal epithelial lining fluid.

In conclusion, severe RSV-LRTI in children is associated with high levels of proteolytic active extracellular GrA and $\mathrm{GrB}$ and expression of $\mathrm{GrB}$ by lymphocytes in the respiratory tract. These findings suggest that the Gr pathway is activated by the local cell-mediated host immune response to RSV. Further studies should elucidate the exact role of Grs in the lungs during RSV disease.

Acknowledgments. We thank B. Smids, T. Dekker and M. Snoek for their excellent technical support, and T.A. Out and P.J.E.J van de Berg for expert discussions on FACS analysis. We thank Peviva AB for providing some ELISA materials.

\section{REFERENCES}

1. Glezen P, Denny FW 1973 Epidemiology of acute lower respiratory disease in children. N Engl J Med 288:498-505

2. Hammer J, Numa A, Newth CJ 1997 Acute respiratory distress syndrome caused by respiratory syncytial virus. Pediatr Pulmonol 23:176-183

3. Bem RA, Bos AP, Matute-Bello G, van Tuyl M, van Woensel JB 2007 Lung epithelial cell apoptosis during acute lung injury in infancy. Pediatr Crit Care Med 8:132-137

4. Viuff B, Tjornehoj K, Larsen LE, Rontved CM, Uttenthal A, Ronsholt L, Alexandersen S 2002 Replication and clearance of respiratory syncytial virus: apoptosis 
is an important pathway of virus clearance after experimental infection with bovine respiratory syncytial virus. Am J Pathol 161:2195-2207

5. Welliver TP, Garofalo RP, Hosakote Y, Hintz KH, Avendano L, Sanchez K, Velozo L, Jafri H, Chavez-Bueno S, Ogra PL, McKinney L, Reed JL, Welliver RC Sr 2007 Severe human lower respiratory tract illness caused by respiratory syncytial virus and influenza virus is characterized by the absence of pulmonary cytotoxic lymphocyte responses. J Infect Dis 195:1126-1136

6. Martin TR, Hagimoto N, Nakamura M, Matute-Bello G 2005 Apoptosis and epithelial injury in the lungs. Proc Am Thorac Soc 2:214-220

7. Hashimoto S, Kobayashi A, Kooguchi K, Kitamura Y, Onodera H, Nakajima H 2000 Upregulation of two death pathways of perforin/granzyme and FasL/Fas in septic acute respiratory distress syndrome. Am J Respir Crit Care Med 161:237-243

8. Matute-Bello G, Liles WC, Steinberg KP, Kiener PA, Mongovin S, Chi EY, Jonas M, Martin TR 1999 Soluble Fas ligand induces epithelial cell apoptosis in humans with acute lung injury (ARDS). J Immunol 163:2217-2225

9. Lieberman J 2003 The ABCs of granule-mediated cytotoxicity: new weapons in the arsenal. Nat Rev Immunol 3:361-370

10. Pinkoski MJ, Hobman M, Heibein JA, Tomaselli K, Li F, Seth P, Froelich CJ, Bleackley RC 1998 Entry and trafficking of granzyme B in target cells during granzyme B-perforin-mediated apoptosis. Blood 92:1044-1054

11. Takayama H, Trenn G, Humphrey W Jr, Bluestone JA, Henkart PA, Sitkovsky MV 1987 Antigen receptor-triggered secretion of a trypsin-type esterase from cytotoxic T lymphocytes. J Immunol 138:566-569

12. Spaeny-Dekking EH, Hanna WL, Wolbink AM, Wever PC, Kummer AJ, Swaak AJ, Middeldorp JM, Huisman HG, Froelich CJ, Hack CE 1998 Extracellular granzymes $\mathrm{A}$ and $\mathrm{B}$ in humans: detection of native species during CTL responses in vitro and in vivo. J Immunol 160:3610-3616

13. Buzza MS, Bird PI 2006 Extracellular granzymes: current perspectives. Biol Chem 387:827-837

14. Everard ML, Swarbrick A, Wrightham M, McIntyre J, Dunkley C, James PD, Sewell HF, Milner AD 1994 Analysis of cells obtained by bronchial lavage of infants with respiratory syncytial virus infection. Arch Dis Child 71:428-432

15. Graham BS, Bunton LA, Wright PF, Karzon DT 1991 Role of T lymphocyte subsets in the pathogenesis of primary infection and rechallenge with respiratory syncytial virus in mice. J Clin Invest 88:1026-1033

16. Hussell T, Openshaw PJ 1998 Intracellular IFN-gamma expression in natural killer cells precedes lung $\mathrm{CD} 8^{+} \mathrm{T}$ cell recruitment during respiratory syncytial virus infection. J Gen Virol 79:2593-2601

17. Openshaw PJ 1989 Flow cytometric analysis of pulmonary lymphocytes from mice infected with respiratory syncytial virus. Clin Exp Immunol 75:324-328

18. van Woensel JB, Lutter R, Biezeveld MH, Dekker T, Nijhuis M, van Aalderen WM, Kuijpers TW 2003 Effect of dexamethasone on tracheal viral load and interleukin-8 tracheal concentration in children with respiratory syncytial virus infection. Pediatr Infect Dis J 22:721-726

19. Spaeny-Dekking EH, Kamp AM, Froelich CJ, Hack CE 2000 Extracellular granzyme A, complexed to proteoglycans, is protected against inactivation by protease inhibitors. Blood 95:1465-1472

20. Schutte B, Henfling M, Kolgen W, Bouman M, Meex S, Leers MP, Nap M, Bjorklund V, Bjorklund P, Bjorklund B, Lane EB, Omary MB, Jornvall H, Ramaekers FC 2004 Keratin 8/18 breakdown and reorganization during apoptosis. Exp Cell Res 297:11-26

21. Cannon MJ, Openshaw PJ, Askonas BA 1988 Cytotoxic T cells clear virus but augment lung pathology in mice infected with respiratory syncytial virus. J Exp Med $168: 1163-1168$
22. Isaacs D, Bangham CR, McMichael AJ 1987 Cell-mediated cytotoxic response to respiratory syncytial virus in infants with bronchiolitis. Lancet 2:769-771

23. Mbawuike IN, Wells J, Byrd R, Cron SG, Glezen WP, Piedra PA 2001 HLA restricted $\mathrm{CD}^{+}{ }^{+}$cytotoxic $\mathrm{T}$ lymphocyte, interferon-gamma, and interleukin- 4 responses to respiratory syncytial virus infection in infants and children. J Infect Dis 183:687-696

24. Mullbacher A, Waring P, Tha HR, Tran T, Chin S, Stehle T, Museteanu C, Simon MM 1999 Granzymes are the essential downstream effector molecules for the control of primary virus infections by cytolytic leukocytes. Proc Natl Acad Sci USA 96:13950-13955

25. Riera L, Gariglio M, Valente G, Mullbacher A, Museteanu C, Landolfo S, Simon MM 2000 Murine cytomegalovirus replication in salivary glands is controlled by both perforin and granzymes during acute infection. Eur J Immunol 30:1350-1355

26. Andrade F, Bull HG, Thornberry NA, Ketner GW, Casciola-Rosen LA, Rosen A 2001 Adenovirus L4-100K assembly protein is a granzyme B substrate that potently inhibits granzyme B-mediated cell death. Immunity 14:751-761

27. Jerome KR, Chen Z, Lang R, Torres MR, Hofmeister J, Smith S, Fox R, Froelich CJ, Corey L 2001 HSV and glycoprotein J inhibit caspase activation and apoptosis induced by granzyme B or Fas. J Immunol 167:3928-3935

28. Miyazaki H, Kuwano K, Yoshida K, Maeyama T, Yoshimi M, Fujita M, Hagimoto N, Yoshida R, Nakanishi Y 2004 The perforin mediated apoptotic pathway in lung injury and fibrosis. J Clin Pathol 57:1292-1298

29. Albertine KH, Soulier MF, Wang Z, Ishizaka A, Hashimoto S, Zimmerman GA, Matthay MA, Ware LB 2002 Fas and fas ligand are up-regulated in pulmonary edema fluid and lung tissue of patients with acute lung injury and the acute respiratory distress syndrome. Am J Pathol 161:1783-1796

30. Klingstrom J, Hardestam J, Stoltz M, Zuber B, Lundkvist A, Linder S, Ahlm C 2006 Loss of cell membrane integrity in puumala hantavirus-infected patients correlates with levels of epithelial cell apoptosis and perforin. J Virol 80:8279-8282

31. Fruth U, Sinigaglia F, Schlesier M, Kilgus J, Kramer MD, Simon MM 1987 A novel serine proteinase (HuTSP) isolated from a cloned human $\mathrm{CD}^{+}$cytolytic $\mathrm{T}$ cell line is expressed and secreted by activated $\mathrm{CD}^{+}$and $\mathrm{CD}^{+}$lymphocytes. Eur $\mathrm{J}$ Immunol 17:1625-1633

32. Tschopp CM, Spiegl N, Didichenko S, Lutmann W, Julius P, Virchow JC, Hack CE Dahinden CA 2006 Granzyme B, a novel mediator of allergic inflammation: its induction and release in blood basophils and human asthma. Blood 108:2290-2299

33. Wagner C, Iking-Konert C, Denefleh B, Stegmaier S, Hug F, Hansch GM 2004 Granzyme B and perforin: constitutive expression in human polymorphonuclear neutrophils. Blood 103:1099-1104

34. Grossman WJ, Ley TJ 2004 Granzymes A and B are not expressed in human neutrophils. Blood 104:906-907

35. Schleimer RP, Jacques A, Shin HS, Lichtenstein LM, Plaut M 1984 Inhibition of T cell-mediated cytotoxicity by anti-inflammatory steroids. J Immunol 132:266-271

36. Zhou J, Olsen S, Moldovan J, Fu X, Sarkar FH, Moudgil VK, Callewaert DM 1997 Glucocorticoid regulation of natural cytotoxicity: effects of cortisol on the phenotype and function of a cloned human natural killer cell line. Cell Immunol 178:108-116

37. Devadas S, Das J, Liu C, Zhang L, Roberts AI, Pan Z, Moore PA, Das G, Shi Y 2006 Granzyme B is critical for T cell receptor-induced cell death of type 2 helper T cells. Immunity 25:237-247

38. Grossman WJ, Verbsky JW, Barchet W, Colonna M, Atkinson JP, Ley TJ 2004 Human $\mathrm{T}$ regulatory cells can use the perforin pathway to cause autologous target cell death. Immunity 21:589-601 